\title{
Multilaboratory Comparison of Quantitative PCR Assays for Detection and Quantification of Fusarium virguliforme from Soybean Roots and Soil
}

\author{
Yuba R. Kandel, James S. Haudenshield, Ali Y. Srour, Kazi Tariqul Islam, Ahmad M. Fakhoury, Patricia Santos, Jie Wang, \\ Martin I. Chilvers, Glen L. Hartman, Dean K. Malvick, Crystal M. Floyd, Daren S. Mueller, and Leonor F. S. Leandro \\ First, twelfth, and thirteenth authors: Department of Plant Pathology and Microbiology, Iowa State University, Ames 50011; second and ninth \\ authors: United States Department of Agriculture-Agricultural Research Service, Urbana, IL 61801; third, fourth, and fifth authors: \\ Department of Plant, Soil and Ag. Systems, Southern Illinois University, Carbondale 62901; sixth author: Department of Biochemistry and \\ Molecular Biology, UNR 1664, N. Virginia St. MS 330, Reno, NV; seventh, and eighth authors: Department of Plant, Soil and Microbial \\ Sciences, Michigan State University, East Lansing 48824; and tenth and eleventh authors: Department of Plant Pathology, University of \\ Minnesota, St. Paul 55108.
}

Accepted for publication 8 September 2015.

\begin{abstract}
Kandel, Y. R., Haudenshield, J. S., Srour, A. Y., Islam, K. T., Fakhoury, A. M., Santos, P., Wang, J., Chilvers, M. I., Hartman, G. L., Malvick, D. K., Flpoyd, C. M., Mueller, D. S., and Leandro, L. F. S. 2015. Multilaboratory comparison of quantitative PCR assays for detection and quantification of Fusarium virguliforme from soybean roots and soil. Phytopathology 105:1601-1611.

The ability to accurately detect and quantify Fusarium virguliforme, the cause of sudden death syndrome (SDS) in soybean, in samples such as plant root tissue and soil is extremely valuable for accurate disease diagnoses and to address research questions. Numerous quantitative realtime polymerase chain reaction (qPCR) assays have been developed for this pathogen but their sensitivity and specificity for $F$. virguliforme have not been compared. In this study, six qPCR assays were compared in five independent laboratories using the same set of DNA samples from fungi,

plants, and soil. Multicopy gene-based assays targeting the ribosomal DNA intergenic spacer (IGS) or the mitochondrial small subunit (mtSSU) showed relatively high sensitivity (limit of detection [LOD] $=0.05$ to $5 \mathrm{pg}$ ) compared with a single-copy gene (FvToxl)-based assay (LOD $=5$ to $50 \mathrm{pg}$ ). Specificity varied greatly among assays, with the FvToxl assay ranking the highest $(100 \%)$ and two IGS assays being slightly less specific (95 to $96 \%)$. Another IGS assay targeting four SDS-causing fusaria showed lower specificity (70\%), while the two mtSSU assays were lowest (41 and 47\%). An IGS-based assay showed consistently highest sensitivity (LOD = $0.05 \mathrm{pg}$ ) and specificity and inclusivity above $94 \%$ and, thus, is suggested as the most useful qPCR assay for $F$. virguliforme diagnosis and quantification. However, specificity was also above $94 \%$ in two other assays and their selection for diagnostics and research will depend on objectives, samples, and materials used. These results will facilitate both fundamental and disease management research pertinent to SDS.
\end{abstract}

Sudden death syndrome (SDS) of soybean has become a major problem in most of the soybean-growing regions of North and South America. SDS may result in minimal to more than $80 \%$ yield loss, depending upon cultivar, time of disease onset, and severity (Roy et al. 1997). In North America, this disease is caused by Fusarium virguliforme (Aoki et al. 2003; Roy 1997; Roy et al. 1997) whereas, in South America, it is caused by $F$. virguliforme, F. tucumaniae, F. brasiliense, and F crassistipitatum (Aoki et al. 2003, 2005, 2012; O'Donnell et al. 2010; Roy et al. 1997; Rupe and Hartman 1999). Since the discovery of SDS in Arkansas in 1971 (Hirrel 1983), the disease has been reported in most soybean-growing states of the United States (Leandro et al. 2012; Rupe et al. 2001); the Canadian province of Ontario (Anderson and Tenuta 1998); and several countries of South America (Leandro et al. 2012), South Africa (Tewoldemedhin et al. 2014) and Asia (Prathuangwong et al. 1996; Sanitchon et al. 2004).

$F$. virguliforme is a soilborne fungus that causes root rot, reducing root biomass in soybean (Roy et al. 1997). The pathogen also produces one (FvTox 1) or more toxins that are translocated from the root to the shoot and cause foliar symptoms (Brar et al. 2011; Pudake et al. 2013). Characteristic foliar symptoms are chlorotic

Corresponding author: L. F. S. Leandro: E-mail address: lleandro@iastate.edu

*The $e$-Xtra logo stands for "electronic extra" and indicates that three supplementary tables are published online.

http://dx.doi.org/10.1094/PHYTO-04-15-0096-R

(C) 2015 The American Phytopathological Society mottling, interveinal necrosis, premature defoliation, and pod abortion (Hartman et al. 2015a; Roy et al. 1997; Rupe and Hartman 1999). These foliar symptoms are similar to those associated with brown stem rot, caused by Cadophora gregata; stem canker, caused by Diaporthe phaseolorum var. caulivora or D. phaseolorum var. meridionalis; and red crown rot, caused by Calonectira ilicicola (Hartman et al. 2015b; Roy et al. 1997; Rupe and Hartman 1999). Distinctive blue sporodochia of $F$. virguliforme are sometimes visible on the root surfaces and lower parts of the soybean stem. These symptoms and signs, along with the absence of brown pith discoloration, help differentiate SDS from diseases with similar symptoms; however, laboratory analyses are needed to support symptom-based diagnoses. Some Fusarium spp. that are phylogenetically closely related to $F$. virguliforme cause root rot on bean but do not cause SDS symptoms on soybean (O'Donnell et al. 2010). Correct diagnosis is key for all aspects of SDS research, from basic research to applied research related to disease management.

Soybean SDS is a difficult disease to manage. Varietal resistance is perhaps the most important tool available (Leandro et al. 2012; Mueller et al. 2003). Soybean genotype screening, a prerequisite for resistance breeding, is challenging because of the erratic response of genotypes in different environments. A previous study (Torto et al. 1996) has shown that genotype reactions under greenhouse conditions sometimes do not correspond to field reactions, possibly due to differences in environmental conditions, stage of the plant in greenhouse versus field during screening, strains of the fungus, or different levels of inoculum in the field versus greenhouse. Accurate 
quantification of the SDS pathogen in the field may improve the reliability of screening assays and the prediction of SDS risk.

Dilution plating of soil samples on semiselective media has been used to estimate $F$. virguliforme density in soil (Cho et al. 2001; Luo et al. 2000, 2001) but this procedure is laborious and time consuming because of the pathogen's slow growth in culture. In addition to the need for prolonged incubation, the medium is only semiselective and it is frequently difficult to detect $F$. virguliforme colonies due to the presence of other Fusarium spp. and other fungi.

Disease diagnosis in clinical laboratories has been revolutionized by real-time quantitative polymerase chain reaction (qPCR) because of several advantages compared with traditional culturebased techniques, immunological methods, and traditional PCR (Bilodeau 2011; Espy et al. 2006; Heid et al. 1996; McCartney et al. 2003; Mumford et al. 2006; Sanzani et al. 2014; Schena et al. 2013; Vincelli and Tisserat 2008). First, qPCR can enable highly sensitive and specific detection of target organisms (nucleic acid) in a variety of specimens without the need to culture the organism. Other important advantages offered by qPCR over conventional PCR are accurate determinations of the initial quantity of target DNA sequence, and eliminating the need for post-PCR processing, such as gel electrophoresis or sequencing of the amplified products. In contrast, some drawbacks of qPCR include occasional type 1 or type 2 errors (false-positive and false-negative results, respectively), and potential difficulties in reproducing results using the same assay in different laboratories (Bustin 2002, 2010; Mbofung et al. 2011).

Several PCR assays for the detection and quantification of $F$. virguliforme were developed over 10 years ago when the fungus was referred to as F. solani f. sp. glycines (Gao et al. 2004; Li and Hartman 2003), with more recent qPCR assays developed within the last 5 years (Mbofung et al. 2011; Wang et al. 2015; Westphal et al. 2014). The qPCR assays targeted various regions of the fungal genome, including the mitochondrial small subunit (mtSSU), ribosomal RNA gene (Gao et al. 2004; Li et al. 2008), and the intergenic spacer (IGS) region of the ribosomal RNA repeats (Wang et al. 2015; Westphal et al. 2014). In addition, after the recent discovery of genes directly involved in toxin production by F. virguliforme (Brar et al. 2011; Pudake et al. 2013), the FvToxl gene was used as a target to design primers and probes for another assay (Mbofung et al.2011). Specificity and sensitivity of the assays may vary based on the type of target region, amplicon size, and its copy number (Chern et al. 2011; Mbofung et al. 2011), as well as the extent to which interfering sequences may be present (nontarget regions which may interact with the primers or probe).

Robustness may be described as an assay's resiliency to potential inhibitors, the ability to perform in different implementations (choice of enzyme supplier, reagents, controls, instrumentations, and protocols) and the employment of control strategies to estimate or prevent false-positive and false-negative results. The presence of multiple Fusarium spp. and other closely related fungi in soybean fields makes specific detection and quantification of $F$. virguliforme challenging. The developers of the assays for $F$. virguliforme have tailored each to the needs of their research focus, partially with a view to the known distribution of SDS-causing species in their region. Thus, a rigorous and systematic comparison of specificity and sensitivity of the $F$. virguliforme $\mathrm{qPCR}$ assays was needed across different laboratories.

The goal of this study was to explore strengths and weaknesses of the existing qPCR assays across multiple implementations when detecting and quantifying $F$. virguliforme from soil and root tissues, and in differentiating among isolates of $F$. virguliforme and related or unrelated species. This study compares the performance of six qPCR assays on the same panel of 76 DNA samples across five different laboratories located in the United States. Knowledge gained from this study will have applications for interpreting assays in diagnostic laboratories, improving research studies, and improving decision making in disease management.

\section{MATERIALS AND METHODS}

Experimental design. A multilaboratory comparison of six independent qPCR assays for detection and quantification of $F$. virguliforme was carried out in five research laboratories located in the United States (Table 1). The assays included were Wang et al. (2015), Fakhoury et al. (this study), Gao et al. (2004), Mbofung et al. (2011), Li et al. (2008), and Westphal et al. (2014). Letters A to F were assigned to the six assays, respectively (Table 2).

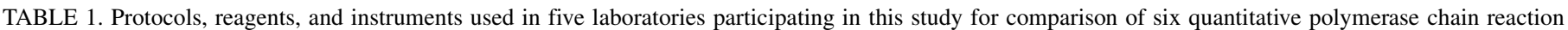
(qPCR) assays developed to detect and quantify Fusarium virguliforme

\begin{tabular}{|c|c|c|c|c|}
\hline $\begin{array}{l}\text { Lab } \\
\text { location }^{z}\end{array}$ & $\begin{array}{l}\text { DNA extraction } \\
\text { protocol }\end{array}$ & $\begin{array}{l}\text { qPCR instrument } \\
\text { and software }\end{array}$ & $\begin{array}{l}\text { Brand of qPCR reagents } \\
\text { (Master Mix) }\end{array}$ & $\begin{array}{l}\text { Data analysis (threshold } \\
\text { adjustment) }\end{array}$ \\
\hline ISU & $\begin{array}{l}\text { DNeasy Plant Mini Kit (Qiagen } \\
\text { Germantown, MD) } \\
\text { for plant and fungus and MoBio } \\
\text { (Carlsbad, CA) Power soil DNA } \\
\text { extraction kit for soil }\end{array}$ & $\begin{array}{l}\text { Bio-Rad iQ5/iCycler iQ5 optical } \\
\text { system software (version 2.1; } \\
\text { Bio-Rad Laboratories, Inc.) }\end{array}$ & $\begin{array}{l}\text { PerfeCTa qPCR SuperMix with } \\
\text { Rox (Quanta Biosciences, } \\
\text { Inc., Gaithersburg, MD) }\end{array}$ & $\begin{array}{l}\text { Cycle threshold was manually } \\
\text { adjusted within the exponential } \\
\text { phase maximizing the efficiency } \\
\text { and } R^{2}\end{array}$ \\
\hline MSU & $\begin{array}{l}\text { DNeasy Plant Mini Kit (Qiagen, } \\
\text { Germantown, MD) }\end{array}$ & $\begin{array}{l}\text { ABI StepOnePlus (Applied } \\
\text { Biosystems), software v2.3 }\end{array}$ & $\begin{array}{l}\text { TaqMan Universal real-time } \\
\text { PCR master mix }(2 \times) \\
\text { (Applied Biosystems) }\end{array}$ & $\begin{array}{l}\text { Baseline threshold was adjusted } \\
\text { automatically by machine }\end{array}$ \\
\hline SIU & $\begin{array}{l}\text { Cetyltrimethylammonium bromide } \\
\text { DNA extraction }\end{array}$ & $\begin{array}{l}\text { Bio-Rad CFX96 Real-time PCR } \\
\text { (Bio-Rad, Hercules, CA), CFX } \\
\text { manager v } 3.1 \text { software }\end{array}$ & $\begin{array}{l}\text { GoTaq Flexi DNA polymerase } \\
\text { from Promega Corp. }\end{array}$ & $\begin{array}{l}\text { Baseline threshold was set } \\
\text { manually using the single } \\
\text { threshold mode at a fluorescence } \\
\text { value above background giving } \\
\text { the best slope and } R^{2}\end{array}$ \\
\hline UI & $\begin{array}{l}\text { FastDNA Spin Kit and FastDNA } \\
\text { Spin Kit for Soil (MP Biomedicals, } \\
\text { Solon, OH) and EZNA MicroElute } \\
\text { DNA Clean Up Kit (Omega Bio-Tek, } \\
\text { Norcross, GA) }\end{array}$ & $\begin{array}{l}\text { Stratagene (Agilent } \\
\text { Technologies, } \\
\text { Santa Clara, CA) Mx3005p } \\
\text { Real-time PCR instrument, } \\
\text { with MxPro } 4.1 \text { software }\end{array}$ & $\begin{array}{l}\text { Invitrogen (Life Technologies, } \\
\text { Grand Island, NY) Platinum } \\
\text { Quantitative PCR SuperMix- } \\
\text { UDG }\end{array}$ & $\begin{array}{l}\text { Amplification-based automatic } \\
\text { threshold adjustment }\end{array}$ \\
\hline UMN & $\begin{array}{l}\text { FastDNA Kit (MP Biomedicals) for } \\
\text { fungal cultures; (Malvick and Grunden } \\
\text { 2005) for plant samples; and PowerSoil } \\
\text { DNA Kit (MoBio Laboratories, } \\
\text { Carlsbad, CA) for soil }\end{array}$ & $\begin{array}{l}\text { Applied Biosystems } 7500 \text { (Life } \\
\text { Technologies, Grand Island, } \\
\text { NY) software version 2.0.6 }\end{array}$ & $\begin{array}{l}\text { Applied Biosystems TaqMan } \\
\text { Gene Expression }\end{array}$ & $\begin{array}{l}\text { Baseline threshold was adjusted } \\
\text { automatically by machine }\end{array}$ \\
\hline
\end{tabular}

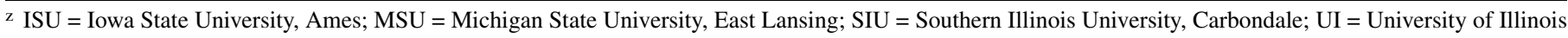
and United States Department of Agriculture-Agricultural Research Service, Urbana; and UMN = University of Minnesota, St. Paul. 


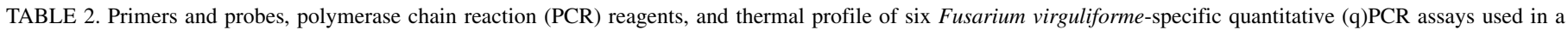
comparison study conducted in five different laboratories

\begin{tabular}{|c|c|c|c|c|}
\hline $\begin{array}{l}\text { Assay and } \\
\text { reference }\end{array}$ & $\begin{array}{l}\text { Target } \\
\text { region }\end{array}$ & $\begin{array}{c}\text { Forward primer }(\mathrm{F}), \text { reverse primer }(\mathrm{R}) \text {, probe internal control sequence, } \\
\text { primers, and } \text { probes }^{\mathrm{z}}\end{array}$ & $\begin{array}{l}\text { PCR mix (final } \\
\text { volume } 20 \mu \mathrm{l})\end{array}$ & Thermal profile \\
\hline \multirow{9}{*}{$\begin{array}{l}\text { A (Haudenshield and } \\
\text { Hartman 2011; } \\
\text { Wang et al. 2015) }\end{array}$} & $\begin{array}{l}\text { 28S-18S } \\
\text { rRNA IGS }\end{array}$ & F 5'-GTAAGTGAGATTTAGTCTAGGGTAGGTGAC-3' & Master mix, $1 \times$ & $2 \mathrm{~min}$ at $50^{\circ} \mathrm{C}$ \\
\hline & & R 5'-GGGACCACCTACCCTACACCTACT-3' & Primers, $500 \mathrm{nM}$ each & $2 \min$ at $95^{\circ} \mathrm{C}$ \\
\hline & & Probe & Probe, $250 \mathrm{nM}$ & $\begin{array}{l}40 \text { cycles of }(15 \mathrm{~s} \\
\text { at } 95^{\circ} \mathrm{C} \text { and } 30 \mathrm{~s} \\
\left.\text { at } 60^{\circ} \mathrm{C}\right)\end{array}$ \\
\hline & & 5'-6FAM-TTTGGTCTAGGGTAGGCCG-/MGBNFQ/-3' & $\begin{array}{l}\text { IC forward primer, } \\
600 \mathrm{nM}\end{array}$ & $\ldots$ \\
\hline & & Internal control target (linearized plasmid) & $\begin{array}{l}\text { IC reverse primer, } \\
200 \mathrm{nM}\end{array}$ & $\cdots$ \\
\hline & & $\begin{array}{l}\text { pJSH-B14 5'-GATACCCAAG TAGTCTTTGC AGTAAATGCA TGC } \\
\text { TTAGGAC GAGAACTCCC ACATCGAGCT GGACATCTGC ATG } \\
\text { TTGATAG GGGACTAGGC ATTAA-3' }\end{array}$ & IC probe, $200 \mathrm{nM}$ & $\cdots$ \\
\hline & & IC-F 5'-CTAGGACGAGAACTCCCACAT-3' & $\begin{array}{l}\text { Bovine serum albumen } \\
\text { (BSA), } 400 \mathrm{ng} / \mu \mathrm{l}\end{array}$ & $\cdots$ \\
\hline & & IC-R 5'-CAATCAGCGGGTGTTTCA-3' & $\ldots$ & $\ldots$ \\
\hline & & $\begin{array}{l}\text { IC-Probe 5'-HEX-TGCTTAGGACGAGAACTCCCACATC-/ } \\
\text { IBFQ/-3' }\end{array}$ & $\ldots$ & $\ldots$ \\
\hline \multirow[t]{6}{*}{$\begin{array}{l}\text { B, (Fakhoury; } \\
\text { this study) }\end{array}$} & $\begin{array}{l}28 \mathrm{~S}-18 \mathrm{~S} \\
\text { rRNA IGS }\end{array}$ & F 5'-GTCAAAATCAGTGTAGGGTAGGT-3' & GoTaq Flexi buffer, $1 \times$ & $2 \min$ at $95^{\circ} \mathrm{C}$ \\
\hline & & R 5'-ACGGGTCGAGACCAGATTT-3' & Primers, $900 \mathrm{nM}$ each & $\begin{array}{l}40 \text { cycles of }(15 \mathrm{~s} \\
\text { at } 95^{\circ} \mathrm{C} \text { and } 60 \mathrm{~s} \\
\left.\text { at } 60^{\circ} \mathrm{C}\right)\end{array}$ \\
\hline & & Probe & Probe, $250 \mathrm{nM}$ & $\ldots$ \\
\hline & & 5'-6FAM-TCCGCAAAAA/ZEN/TCAGGGCATCCCAC/IABkFQ-3' & $\mathrm{MgCl}_{2}, 3 \mathrm{mM}$ & $\ldots$ \\
\hline & & & dNTP, $0.2 \mathrm{mM}$ each & $\cdots$ \\
\hline & & & $\begin{array}{l}\text { GoTaq DNA } \\
\text { polymerase, } 1.25 \mathrm{U}\end{array}$ & $\cdots$ \\
\hline \multirow{6}{*}{$\begin{array}{l}\text { C, (Gao et al. 2004; } \\
\text { Haudenshield and } \\
\text { Hartman 2011) }\end{array}$} & mtSSU rRNA & F 5'-GATACCCAAGTAGTCTTTGCAGTAAATG-3' & Master mix, $1 \times$ & $2 \mathrm{~min}$ at $50^{\circ} \mathrm{C}$ \\
\hline & & $\begin{array}{l}\text { R 5'-TTAATGCCTAGTCCCCTATCAACAT-3' } \\
\text { Probe }\end{array}$ & $\begin{array}{l}\text { Primers, } 900 \mathrm{nM} \text { each } \\
\text { Probe, } 200 \mathrm{nM}\end{array}$ & $\begin{array}{l}2 \text { min at } 95^{\circ} \mathrm{C} \\
40 \text { cycles of }(15 \mathrm{~s} \\
\text { at } 95^{\circ} \mathrm{C} \text { and } 30 \mathrm{~s} \\
\left.\text { at } 60^{\circ} \mathrm{C}\right)\end{array}$ \\
\hline & & 5'-6FAM-TGAATGCCATAGGTCAGAT-/MGBNFQ/-3' & $\mathrm{MgCl}_{2}, 6.0 \mathrm{mM}$ & $\ldots$ \\
\hline & & Internal control target (synthetic sequence) & $\begin{array}{l}\text { Internal control } \\
\text { probe, } 150 \mathrm{nM}\end{array}$ & $\ldots$ \\
\hline & & $\begin{array}{l}\text { FsgIC-sEquation 5'-GATACCCAAG TAGTCTTTGC AGTAAATGCA } \\
\text { TGCTTAGGAC GAGAACTCCC ACATCGAGCT GGACATCTGC } \\
\text { ATGTTGATAG GGGACTAGGC ATTAA-3' }\end{array}$ & $\begin{array}{l}\text { Internal control } \\
\text { target, } 50 \mathrm{ymol}\end{array}$ & $\cdots$ \\
\hline & & CoreIC-Probe 5'-HEX-TGC TTA GGA CGA GAA CTC CCA CAT C-IBFQ-3' & $\mathrm{BSA}, 400 \mathrm{ng} / \mu \mathrm{l}$ & $\ldots$ \\
\hline \multirow{4}{*}{$\begin{array}{l}\text { D, (Mbofung } \\
\text { et al. 2011) }\end{array}$} & FvTox1 & F 5'-GCA GGC CAT GTT GGT TCT GTA-3' & Master mix, $1 \times$ & $10 \mathrm{~min}$ at $95^{\circ} \mathrm{C}$ \\
\hline & & R 5'-GCA CGT AAA GTG AGT CGT CTC ATC-3' & Primers, $300 \mathrm{nM}$ each & $\begin{array}{l}40 \text { cycles of }(15 \mathrm{~s} \\
\text { at } 95^{\circ} \mathrm{C} \text { and } 45 \mathrm{~s} \\
\left.\text { at } 60^{\circ} \mathrm{C}\right)\end{array}$ \\
\hline & & Probe & Probe, $200 \mathrm{nM}$ & $\ldots$ \\
\hline & & 5'-6-FAM ACT CAG CGC CCA GGA-/MGBNFQ/-3' & & $\ldots$ \\
\hline \multirow{6}{*}{$\begin{array}{l}\text { E, (Haudenshield and } \\
\text { Hartman 2011; Li } \\
\text { et al. 2008) }\end{array}$} & mtSSU rRNA & F 5'-GGCTGAACTGGCAACTTGGA-3' & Master mix, $1 \times$ & $2 \mathrm{~min}$ at $50^{\circ} \mathrm{C}$ \\
\hline & & $\begin{array}{l}\text { R 5'-CAAAGCTTCATTCAATCCTAATACAATC-3' } \\
\text { Probe 5'-6FAM-TCTTCTAGGATGGGCTGGT-/MGBNFQ/-3' }\end{array}$ & $\begin{array}{l}\text { Primers, } 300 \mathrm{nM} \text { each } \\
\text { Probe, } 200 \mathrm{nM}\end{array}$ & $\begin{array}{l}2 \text { min at } 95^{\circ} \mathrm{C} \\
40 \text { cycles of }(15 \mathrm{~s} \\
\text { at } 95^{\circ} \mathrm{C} \text { and } 30 \mathrm{~s} \\
\left.\text { at } 60^{\circ} \mathrm{C}\right)\end{array}$ \\
\hline & & Internal control target (synthetic sequence) & $\mathrm{MgCl}_{2}, 6.0 \mathrm{mM}$ & $\ldots$ \\
\hline & & $\begin{array}{l}\text { FvLiIC-sEquation 5'-GGCTGAACTG GCAACTTGGA CATGCTT } \\
\text { AGG ACGAGAACTC CCACATCGAG CTGGACATCT GCGATT } \\
\text { GTAT TAGGATTGAA TGAAGCTTTG-3' }\end{array}$ & $\begin{array}{l}\text { Internal control probe, } \\
150 \mathrm{nM}\end{array}$ & $\ldots$ \\
\hline & & CoreIC-Probe 5'-HEX-TGC TTA GGA CGA GAA CTC CCA CAT C-IBFQ-3' & $\begin{array}{l}\text { Internal control target, } \\
50 \text { ymol }\end{array}$ & $\ldots$ \\
\hline & & & $\mathrm{BSA}, 400 \mathrm{ng} / \mu \mathrm{l}$ & $\ldots$ \\
\hline \multirow[t]{3}{*}{$\begin{array}{l}\text { F, (Westphal } \\
\text { et al. 2014) }\end{array}$} & $\begin{array}{l}\text { 28S-18S } \\
\text { rRNA IGS }\end{array}$ & 5'-GGTGGTGCGGAAGGTCT-3' & Master mix, $1 \times$ & $2 \mathrm{~min}$ at $50^{\circ} \mathrm{C}$ \\
\hline & & 5'-CCCTACACCTTTCGTACCAT-3' & Primers, $450 \mathrm{nM}$ each & $10 \mathrm{~min}$ at $95^{\circ} \mathrm{C}$ \\
\hline & & 5'-6FAM-ATAGGGTAGGCGGATCTGACTTGGCG-/TAMRA/-3' & Probe, $200 \mathrm{nM}$ & $\begin{array}{l}40 \text { cycles of }(15 \mathrm{~s} \\
\text { at } 95^{\circ} \mathrm{C} \text { and } 60 \mathrm{~s} \\
\left.\text { at } 66^{\circ} \mathrm{C}\right)\end{array}$ \\
\hline
\end{tabular}

y IGS = intergenic spacer of ribosomal RNA repeats, rRNA = ribosomal RNA, and mtSSU = mitochondrial small subunit ribosomal RNA gene.

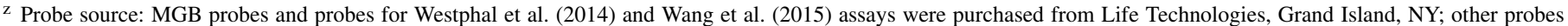
were purchased from Integrated DNA Technologies, Inc. (IDT), Coralville, IA. Internal control DNA was ordered from Addgene, Cambridge, MA (http://www.addgene. org) or received from Hartman Lab (University of Illinois and United States Department of Agriculture-Agricultural Research Service, Urbana). Primer source: Wang et al. (2015) assay from Sigma-Aldrich as high-performance liquid chromatography purified oligos; Fakhoury et al. (this study), Gao et al. (2004), Mbofung et al. (2011), Li et al. (2008), and Westphal et al. (2014) assays from IDT. 
All six assays were run using the same panel of DNA samples from pure cultures and from plant and soil samples in each of the participating laboratories. To determine the influence of laboratory variation on the qPCR assays, amplification was done in each laboratory with their unique working environments, brands of reagents and consumables, instrumentation, and method of data analysis (Table 1).

Sample preparation. In total, 76 DNA samples were tested, including 54 DNA samples from pure fungal cultures (Table 3) and 22 DNA samples from soybean root tissue or soil (Table 4). The 54 DNA samples from pure cultures comprised of 19 isolates of $F$. virguliforme from different geographic regions and 35 isolates of other fungal species that included 13 Fusarium spp., three of which (F. brasiliense, $F$. crassistipitatum, and $F$. tucumaniae) also cause SDS, and two other species frequently found in soybean fields (Macrophomina phaseolina and Rhizoctonia solani) (Table 3). Species identification of all isolates was confirmed by partial sequencing of the translation elongation factor (EF-1 $\alpha)$ using the primer sequence EF-1H and EF-2T (O'Donnell et al. 1998). Isolates were obtained from participating laboratories and from the United States Department of Agriculture-Agricultural Research Service Culture Collection (National Center for Agricultural Utilization Research, Peoria, IL). To validate assay specificity and sensitivity for quantifying $F$. virguliforme from field and greenhouse materials, 22 samples from roots $(n=11)$ and soil $(n=11)$ were collected and tested (Table 4). Root and soil samples were collected from either the greenhouse $(n=7)$ or field $(n=15)$ (Table 4$)$. Of the 22 DNA from root and soil samples, 12 were known or suspected to be infected or infested by $F$. virguliforme and 10 were presumably noninfested.

DNA was extracted following standard protocols in each laboratory (Table 1) and submitted to Iowa State University (ISU) for quantification and preparation of a single set of DNA samples to use throughout the study. Upon receipt, DNA samples were stored at $-20^{\circ} \mathrm{C}$ until needed. Quantity and quality of the DNA were determined using a NanoDrop 1000 spectrophotometer (Thermo Fisher Scientific, Wilmington, DE). After the DNA concentration was determined, each DNA sample from pure culture was diluted to $1 \mathrm{ng} / \mu \mathrm{l}$ in DNase-, RNase-, and protease-free Tris-EDTA buffer $(10 \mathrm{mM}$ Tris and $1 \mathrm{mM}$ EDTA, $\mathrm{pH} 8.0 \pm 0.1)$. Concentrations of the DNA from root and soil samples were quantified using the same method but concentrations were not adjusted. To reduce potential biases, the DNA samples were provided double blind to each laboratory by assigning a random number to each sample, which was only decoded after completion of the study, except for the F. virguliforme isolate Mont-1 reference DNA, used for standard curves.

After receiving the coded DNA samples from ISU, each participating laboratory prepared dilutions. For DNA from pure cultures, dilutions were made at $10^{-1}, 10^{-3}$, and $10^{-5}$, resulting in $100 \mathrm{pg} / \mu \mathrm{l}, 1 \mathrm{pg} / \mu \mathrm{l}$, and $10 \mathrm{fg} / \mu \mathrm{l}$. For DNA from root and soil samples, dilutions were made at $10^{-1}, 10^{-2}$, and $10^{-3}$. Serial dilution (10-fold) of the reference $F$. virguliforme isolate Mont-1 DNA were prepared from stock at $1 \mathrm{ng} / \mu \mathrm{l}$ to produce the following concentrations: $1 \mathrm{ng} / \mu \mathrm{l}, 100 \mathrm{pg} / \mu \mathrm{l}, 10 \mathrm{pg} / \mu \mathrm{l}, 1 \mathrm{pg} / \mu \mathrm{l}, 100 \mathrm{fg} / \mu \mathrm{l}$, $10 \mathrm{fg} / \mu \mathrm{l}$, and $1 \mathrm{fg} / \mu \mathrm{l}$. To further eliminate potential extraneous variables from the experiment, all primers, probes, and internal control target sequences (where used) required for the assays were derived from a single custom synthesis of each. These were then divided into identical substocks and distributed among the participating laboratories by the laboratory where the assay was developed. Although the DNA were assayed blindly by each laboratory, the assays themselves (A through F) were known by necessity: each laboratory implemented the assays following provided protocols but with their own real-time PCR instruments and preferred master mix.

qPCR amplification. The assays were conducted with two technical replications of each of the three dilutions, for a total of six reactions for each DNA sample. qPCR assays were performed in a total volume of $20 \mu \mathrm{l}$ containing $5 \mu \mathrm{l}$ of test DNA. All the reactions were performed in 96-well plates. Each 96-well plate included DNA of 76 unknown DNA samples, 2 nontemplate water controls (NTC), and 14 DNA samples of isolate Mont-1 for the standard curve determination. Each of seven concentrations of Mont-1 DNA was run in duplicate in each plate to produce a standard curve, to act as a positive control, and to evaluate the limit of detection (LOD) of the assay. Thus, each of the six assays was performed in 552 reactions per lab (three dilutions $\times$ two technical replications $\times 92$ reactions per plate), for a total of 2,760 reactions (five laboratories $\times 552$ reactions per lab). Because of occasional errors in set-up, a few reactions were rerun on separate plates, along with the requisite standard curves. Each assay's reaction mix and cycling conditions were followed as described in the assay protocol provided by each laboratory (Table 2). Each laboratory used the same brand and type of Master Mix for all six assays that they commonly use in that laboratory. Amplification conditions and the other reagents used for this study were the same as those used when the assays were developed and optimized.

Data handling and analysis. The cycle threshold was set according to the standard practice of each laboratory. In two of the five laboratories, the threshold value was set manually according to the manufacturer's instructions within the exponential phase of amplification, maximizing the efficiency and coefficient of determination $\left(R^{2}\right)$. In the other three laboratories, the threshold was calculated automatically by the thermocycler software (Table 1).

Standard curves were generated by plotting the quantification cycle threshold $\left(\mathrm{C}_{\mathrm{q}}\right)$ value against the base $\mathrm{1}_{10} \log$ of the initial concentration of the reference DNA. The resulting standard curve was used to determine quantity of test DNA, as well as to compare the amplification efficiency of assays across laboratories. The $R^{2}$ for each run was also calculated using the standard curve data. The LOD for each assay was determined in each laboratory as the lowest concentration of the standard DNA that could be detected in at least $95 \%$ of the assay runs. For example, each standard DNA concentration was run 12 times for each assay; thus, the lowest concentration that was amplified in all 12 runs was considered to be the LOD. After defining the LOD, data from standard DNA below the assay LOD were excluded from standard curves. The absolute quantity of the test DNA sample was quantified by comparing the $\mathrm{C}_{\mathrm{q}}$ values of the sample to the standard curve using the software associated with each thermocycler. Quantification was done only within the range of amplification of the standard curve (i.e., the DNA quantity was not extrapolated outside the range. The test result was defined as positive when the quantity of DNA was equal to or above the LOD and negative when below the LOD. Abnormal amplification in any well was considered missing data.

Assays were evaluated for efficiency (the relative increase in PCR product per cycle), specificity (the ability to exclude from detection any non- $F$. virguliforme species), inclusivity (the ability to detect all $F$. virguliforme isolates), and sensitivity (power to detect small quantity) across and within each laboratory. Amplification efficiency of each run was determined using the slope of the standard curve generated by the serially diluted reference isolate. Inclusivity of the assays was determined based on positive results from the most concentrated DNA samples of all $19 \mathrm{~F}$. virguliforme isolates originating from different geographical regions. The inclusivity was calculated as the percentage of DNA samples correctly identified as positive out of the total positive samples from pure culture, as explained below:

$$
\text { Inclusivity }(\%)=\frac{\text { number of true positives at } 0.5 \mathrm{ng} \text { DNA concentration }}{\text { total number of } F \cdot \text { virguliforme samples }} \times 100
$$

Specificity for each assay was determined based on results from the most concentrated DNA samples from pure cultures, as the rate 
TABLE 3. Number of fungal DNA samples detected as false negatives and false positives by six qPCR assays developed for the detection and quantification of Fusarium virguliforme ${ }^{\mathrm{w}}$

\begin{tabular}{|c|c|c|c|c|c|c|c|c|c|}
\hline \multirow[b]{3}{*}{ Code $^{y}$} & \multirow[b]{3}{*}{ Species } & \multirow[b]{3}{*}{ Isolate } & \multirow[b]{3}{*}{ DNA source ${ }^{z}$} & \multicolumn{6}{|c|}{ Assay $^{x}$} \\
\hline & & & & A & B & $\mathrm{C}$ & $\mathrm{D}$ & E & $\mathrm{F}$ \\
\hline & & & & $(n=10)$ & $(n=10)$ & $(n=10)$ & $(n=10)$ & $(n=10)$ & $(n=6)$ \\
\hline $\mathrm{CH} 03$ & F. virguliforme & Fv-2 & SIU & 2 & 2 & 2 & 2 & 1 & 0 \\
\hline $\mathrm{CH} 04$ & F. virguliforme & LL0003 & ISU & 0 & 0 & 0 & 0 & 0 & 1 \\
\hline $\mathrm{CH} 08$ & F. virguliforme & LL0014 & ISU & 0 & 0 & 0 & 1 & 0 & 1 \\
\hline CH11 & F. virguliforme & LP & UI & 1 & 4 & 4 & 10 & 4 & 4 \\
\hline $\mathrm{CH} 18$ & F. virguliforme & 4 & UMN & 0 & 0 & 0 & 0 & 0 & 0 \\
\hline CH19 & F. virguliforme & FSG1002 & UI & 0 & 0 & 0 & 0 & 0 & 0 \\
\hline $\mathrm{CH} 23$ & F. virguliforme & LL0032 & ISU & 0 & 0 & 0 & 1 & 0 & 0 \\
\hline $\mathrm{CH} 30$ & F. virguliforme & Mont-1 & UI & 0 & 0 & 0 & 0 & 0 & 0 \\
\hline $\mathrm{CH} 33$ & F. virguliforme & Fv-3 & SIU & 0 & 0 & 0 & 1 & 0 & 0 \\
\hline $\mathrm{CH} 34$ & F. virguliforme & 1 & UMN & 0 & 0 & 0 & 0 & 0 & 0 \\
\hline $\mathrm{CH} 35$ & F. virguliforme & STJ-3A & MSU & 0 & 0 & 0 & 0 & 1 & 0 \\
\hline CH55 & F. virguliforme & VB-1 & MSU & 0 & 0 & 0 & 0 & 0 & 0 \\
\hline Total & $\ldots$ & $\ldots$ & $\ldots$ & 5 & 7 & 7 & 25 & 7 & 8 \\
\hline \multicolumn{10}{|c|}{ False positives } \\
\hline $\mathrm{CH} 01$ & F. solani & $76-\mathrm{L} 2$ & ISU & 0 & 0 & 4 & 0 & 9 & 0 \\
\hline $\mathrm{CH} 10$ & F. solani & 7 & UMN & 0 & 0 & 1 & 0 & 1 & 0 \\
\hline $\mathrm{CH} 21$ & F. solani & $11-\mathrm{T} 3$ & ISU & 1 & 4 & 6 & 0 & 10 & 0 \\
\hline $\mathrm{CH} 29$ & F. solani & 9 & UMN & 0 & 0 & 3 & 0 & 1 & 0 \\
\hline $\mathrm{CH} 32$ & F. solani & $42-\mathrm{T} 1$ & ISU & 3 & 2 & 4 & 0 & 10 & 0 \\
\hline $\mathrm{CH} 42$ & F. solani & $5 \mathrm{~L} 5$ & ISU & 0 & 0 & 5 & 0 & 10 & 0 \\
\hline $\mathrm{CH} 47$ & F. solani & $35-\mathrm{T} 7$ & ISU & 1 & 0 & 4 & 0 & 10 & 0 \\
\hline $\mathrm{CH} 51$ & F. solani & 6 & UMN & 0 & 1 & 4 & 0 & 10 & 0 \\
\hline CH54 & F. solani & 8 & UMN & 0 & 0 & 1 & 0 & 0 & 0 \\
\hline $\mathrm{CH} 02$ & F. oxysporum & Fo-2 & SIU & 0 & 0 & 2 & 0 & 2 & 1 \\
\hline $\mathrm{CH} 43$ & F. cuneirostrum & U7506J & UI & 0 & 10 & 10 & 0 & 10 & 0 \\
\hline $\mathrm{CH} 13$ & F. cuneirostrum & NRRL 36024 & NRRL & 0 & 10 & 10 & 0 & 9 & 1 \\
\hline $\mathrm{CH} 25$ & F. acuminatum & $98 \mathrm{~T} 3$ & ISU & 0 & 0 & 2 & 0 & 1 & 0 \\
\hline $\mathrm{CH} 44$ & F. acuminatum & 13 & UMN & 0 & 0 & 2 & 0 & 2 & 0 \\
\hline CH38 & F. eumartii & NRRL 22574 & NRRL & 0 & 0 & 10 & 0 & 4 & 0 \\
\hline $\mathrm{CH} 45$ & F. eumartii & NRRL 22412 & NRRL & 0 & 1 & 8 & 0 & 8 & 0 \\
\hline $\mathrm{CH} 24$ & F. graminearum & 12 & UMN & 0 & 0 & 1 & 0 & 1 & 0 \\
\hline $\mathrm{CH} 26$ & F. graminearum & $253 \mathrm{~L} 4$ & ISU & 5 & 3 & 6 & 0 & 5 & 2 \\
\hline $\mathrm{CH} 06$ & F. phaseoli & NRRL 22276 & NRRL & 2 & 10 & 10 & 0 & 10 & 0 \\
\hline $\mathrm{CH} 31$ & F. phaseoli & NRRL 31156 & NRRL & 0 & 10 & 10 & 1 & 10 & 0 \\
\hline $\mathrm{CH} 28$ & F. javanicum & NRRL 22387 & NRRL & 0 & 0 & 9 & 0 & 6 & 0 \\
\hline $\mathrm{CH} 46$ & F. redolens & 14 & UMN & 0 & 0 & 1 & 0 & 0 & 0 \\
\hline $\mathrm{CH} 48$ & F. sporotrichioides & Z9L1 & ISU & 0 & 0 & 2 & 0 & 1 & 0 \\
\hline $\mathrm{CH} 27$ & Macrophomina phaseolina & Pine Tree & UI & 0 & 0 & 1 & 0 & 3 & 0 \\
\hline CH53 & Rhizoctonia solani & RS1039 & UI & 0 & 0 & 1 & 0 & 1 & 0 \\
\hline Total & $\ldots$ & $\ldots$ & $\ldots$ & 19 & 104 & 185 & 1 & 207 & 8 \\
\hline
\end{tabular}

${ }^{\mathrm{w}}$ Results were based only on the most concentrated (0.5 ng) DNA samples.

x Assay A = Wang et al. (2015), B = Fakhoury et al. (this study), C = Gao et al. (2004), D = Mbofung, et al. (2011), E = Li et al. (2008), and F = Westphal et al. (2014). Sample size $(n)$ for each of the isolates was 10 (five laboratories $\times$ two technical reps) for five assays from A to E. Assay F did not amplify normally in two laboratories at Iowa State University, Ames (ISU) and Michigan State University, East Lansing (MSU); therefore, the sample size of each isolate for the assay was 6.

y $\mathrm{CH}=$ DNA from pure culture. $\mathrm{CH03}$ was not amplified at MSU because of an error during handling the sample. CH11 might have been contaminated during sample preparation. The sample was not amplified in many cases and concentration of DNA was very low in positive results, even though same amount of DNA was used in all of the DNA samples from pure cultures. Resequencing also did not confirm F. virguliforme. Total $=$ total false negatives or false positives across all isolates.

${ }^{\mathrm{z}}$ SIU = Southern Illinois University, Carbondale; UI = University of Illinois and the United States Department of Agriculture-Agricultural Research Service (USDA-ARS), Urbana; UMN = University of Minnesota, St. Paul; and NRRL = USDA-ARS Culture Collection. 
TABLE 4. Quantity of Fusarium virguliforme DNA (pg) measured by six quantitative polymerase chain reaction assays in serially diluted $\left(10^{-1}, 10^{-2}\right.$, and $10^{-3}$ ) field samples, averaged over five laboratories ${ }^{\mathrm{w}}$

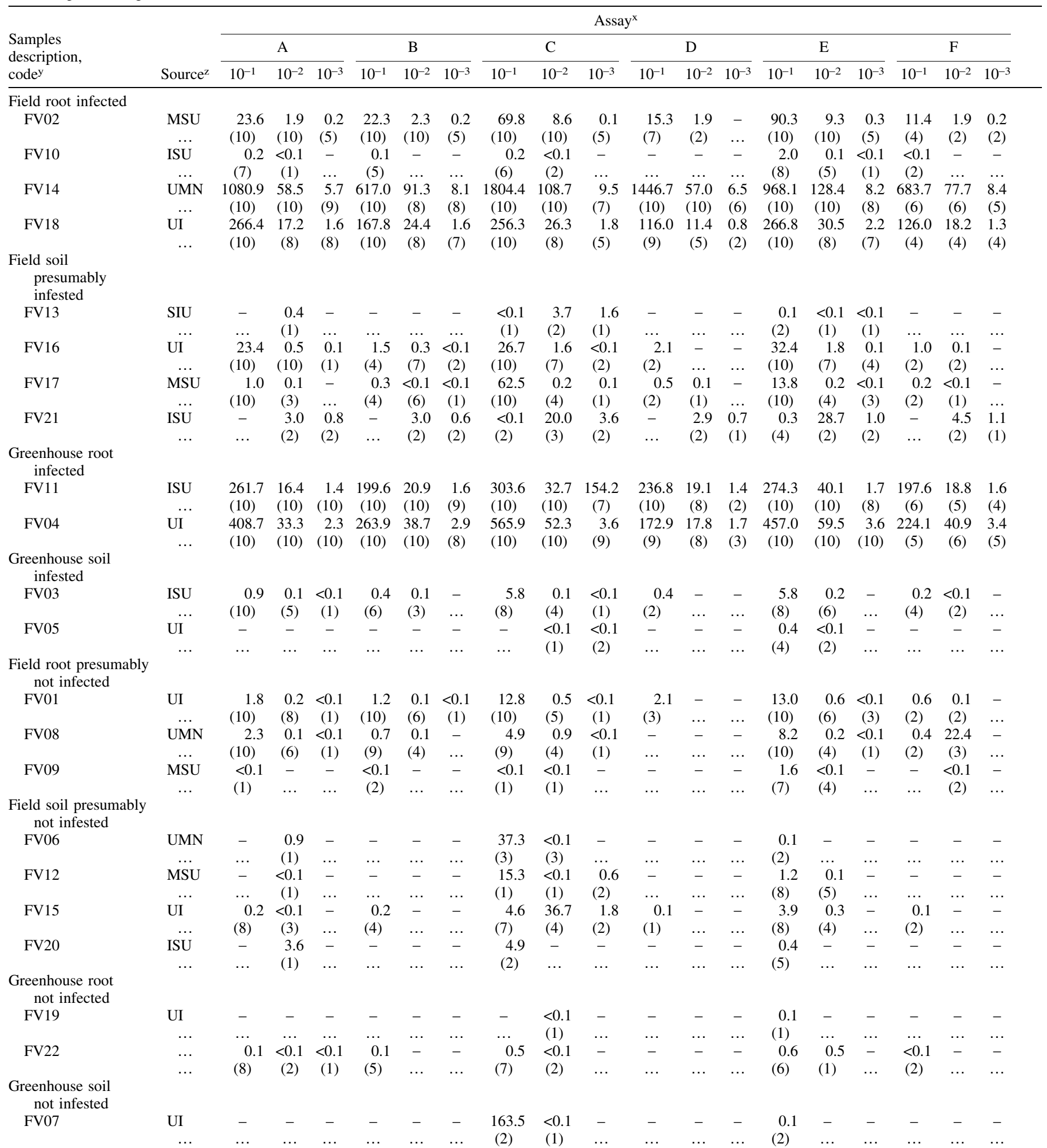

${ }^{w}$ Quantity of DNA quantity for each sample is the average of 10 runs (five laboratories $\times$ two technical reps) for assays A to E. Assay F did not amplify normally in two universities (Iowa State University, Ames [ISU] and Michigan State University, East Lansing [MSU]); therefore, the quantity for assay F is the average of only six runs. Numbers in parenthesis are the number of samples identified as positive out of the total runs ( 6 for assay $\mathrm{F}$ and 10 for the other assays) $-=$ DNA was not amplified.

x Assay A = Wang et al. (2015), B = Fakhoury et al. (this study), C = Gao et al. (2004), D = Mbofung, et al. (2011), E = Li et al. (2008), and F = Westphal et al. (2014).

y FV = DNA from soybean root and soil samples.

${ }^{\mathrm{z}}$ SIU = Southern Illinois University, Carbondale; UI = University of Illinois and the United States Department of Agriculture-Agricultural Research Service, Urbana; and UMN = University of Minnesota, St. Paul. 
of false amplification in $F$. virguliforme-negative specimens comprising a panel of most closely related non- $F$. virguliforme species and other fungal species commonly found in corn and soybean fields. Specificity was calculated using the following formula (Lemmon and Gardner 2008):

Specificity $=1-\frac{\text { number of false positives at } 0.5 \mathrm{ng} \text { DNA concentration }}{\text { false positives }+ \text { true negatives }} \times 100$

Assay sensitivity was determined based on (i) the LOD calculated from the standard curve and (ii) true-positive rate in confirmed positive samples tested in different dilutions. DNA samples from pure cultures were run in three dilutions $\left(5 \times 10^{-1}, 5 \times 10^{-3}\right.$, and $5 \times 10^{-5} \mathrm{ng} /$ well) to determine the sensitivity of those assays. The true-positive rate was calculated as the percentage of samples correctly detected as positives, using the formula given below:

$$
\text { True positive rate }=\frac{\text { number of true positives }}{\text { total number of } F \text {. virguliforme samples }} \times 100
$$

Analysis of variance was used to determine variation in results attributed to laboratories and protocols for specificity and inclusivity of each assay using proc GLM in SAS (SAS Institute Inc., Cary, NC). Means were separated using Fisher's least significant difference value at the $P=0.05$ significance level.

\section{RESULTS}

Amplification efficiency of qPCR assays. The efficiency of PCR to amplify target DNA was different among assays within a laboratory and among laboratories within an assay. The individual efficiency per run ranged from 71 to $132 \%$ across all assays and laboratory conditions (data not shown). On average, assay D showed the highest deviation from $100 \%$ for the amplification efficiency (Table 5). Assay F did not amplify normally at ISU and resulted in close to $50 \%$ efficiency at Michigan State University (MSU); therefore, assay $\mathrm{F}$ data from these two universities were excluded from the analysis. $R^{2}$, the fit of all data to the standard curve plot, was above 0.96 in all assays conducted in all laboratories (Table 5). Occasional abnormal amplification was noticed in a few wells and they were handled as missing data.

Most of the assays had no amplification in the NTC wells. One assay (F) exhibited weak amplification in some NTC wells in all the laboratories but DNA quantities (cycle thresholds) in each of those false-positive wells fell below the LOD for the assay; therefore, these data had no impact on the results.

LOD and analytical sensitivity of the qPCR assays. Cycle threshold values of each of the concentrations for all six assays and runs have been provided in Supplementary Table S1. The interassay and interlaboratory variation was high for the LOD. The LOD ranged from 50 to $0.05 \mathrm{pg}$, depending on assay and laboratory
(Table 6). The highest sensitivity was observed in assay A, with the detection limit of $0.05 \mathrm{pg}$ in all of the laboratories and runs. Assays B, C, E, and F reported a 0.05-pg LOD in some laboratories but they were not as consistent across laboratories (Table 6). The lowest sensitivity (high LOD) was observed in assay D, along with a high variation across laboratories (Table 6).

The positive detection rate for known $F$. virguliforme-positive isolates in three different concentrations, which were used to determine the sensitivity, was significantly different among the assays $(P<0.001)$. Assays A, B, C, E, and F accurately identified 93 to $97 \%$ while assay D, which had the lowest LOD, amplified $87 \%$ of $F$. virguliforme isolates in the samples with the most concentrated DNA (DNA at $0.5 \mathrm{ng} /$ well). None of the assays amplified more than $22 \%$ of the most diluted samples (0.05 pg of DNA) (Table 6). At a concentration of $5 \mathrm{pg}$ of DNA, assays A (92\% detection) and D (27\% detection) showed the highest and lowest true-positive rates, respectively (Table 6).

Specificity and Inclusivity of the qPCR assays. Evaluation of specificity for identification of $F$. virguliforme determined that the assays varied in ability to distinguish $F$. virguliforme from other species $(P<0.01)$. Overall specificity ranged from 100 to $41 \%$ (Table 7). The highest specificity among the six assays compared was observed in assay D (100\%; Table 7), which falsely amplified 1 of 350 of the negative samples. Assay D was followed by assays $\mathrm{F}$ and A, with specificity of $96 \%$ (8 of 210 negative samples were misidentified) and 95\% (19 of 350 negative samples were misidentified), respectively. Assay E was the least specific among the assays compared, with specificity of $41 \%$, which amplified 207 of 350 of the non-F. virguliforme samples (Tables 3 and 7).

Assays with low specificity were unable to differentiate $F$. virguliforme from other SDS and closely related bean root rot pathogens. Assay E amplified other SDS- and bean-root-rot-causing Fusarium spp. F. cuneirostrum and $F$. phaseoli and some $F$. solani isolates; isolates of $F$. eumartii, F. javanicum, and F. oxysporum, and a few $F$. solani were falsely amplified in some laboratory conditions. Likewise, assay $\mathrm{C}$ showed false amplification to other SDS- and closely related bean-root-rot-causing fusaria and $F$. eumartii. In addition, $F$. graminearum, $F$. oxysporum, $F$. sporotrichioides, and $F$. solani, also produced false-positive results in some laboratories. Assay B was unable to discriminate between $F$. virguliforme and other SDS- and bean-root-rot-causing pathogens (Table 3). Assays A and F demonstrated a few false amplifications in some laboratories but none of the species were consistently misidentified as $F$. virguliforme in all of the laboratories. Except for a few sporadic cases for assay $\mathrm{C}$ and $\mathrm{E}$, all assays correctly showed negative response to isolates of M. phaseolina and $R$. solani (Table 3 ).

Of the total number of tests ( 19 confirmed $F$. virguliforme isolates $\times$ five laboratories $\times$ two replications), the inclusivity of the qPCR assays ranged from 87 to $97 \%$ (Table 7). The DNA from isolate $\mathrm{CH} 03$ was classified as a negative at MSU in all assays but this was traced to an error during sample preparation. Mixed results were

TABLE 5. Efficiency of six quantitative polymerase chain reaction assays developed to detect and quantify Fusarium virguliforme as measured in laboratories in five locations ${ }^{\mathrm{x}}$

\begin{tabular}{|c|c|c|c|c|c|c|}
\hline \multirow[b]{2}{*}{ Location $^{z}$} & \multicolumn{6}{|c|}{ Assayy } \\
\hline & A & B & $\mathrm{C}$ & $\mathrm{D}$ & E & $\mathrm{F}$ \\
\hline ISU & $83.1 \pm 1.63$ & $96.2 \pm 1.79$ & $88.3 \pm 3.56$ & $91.4 \pm 1.71$ & $89.4 \pm 3.35$ & NA \\
\hline MSU & $94.9 \pm 0.67$ & $102.0 \pm 0.88$ & $98.8 \pm 1.48$ & $88.3 \pm 1.06$ & $95.4 \pm 0.78$ & NA \\
\hline UI & $101.7 \pm 1.34$ & $102.5 \pm 0.92$ & $102.4 \pm 1.01$ & $108.4 \pm 3.64$ & $100.2 \pm 0.49$ & $100.7 \pm 0.91$ \\
\hline UMN & $87.3 \pm 0.91$ & $88.9 \pm 0.73$ & $83.2 \pm 1.00$ & $78.0 \pm 1.27$ & $78.8 \pm 1.33$ & $119.7 \pm 3.50$ \\
\hline
\end{tabular}

${ }^{x}$ All assays obtained $>0.98 R^{2}$ except assay C (0.97) and assay F (0.96) at Southern Illinois University, Carbondale (SIU). NA = not available. Assay F failed to amplify normally at Iowa State University, Ames (ISU) and Michigan State University, East Lansing (MSU); therefore, data from those universities for assay F were not used for analysis.

y Assay A = Wang et al. (2015), B = Fakhoury et al. (this study), C = Gao et al. (2004), D = Mbofung, et al. (2011), E = Li et al. (2008), and F = Westphal et al. (2014).

${ }^{\mathrm{z}} \mathrm{UI}=$ University of Illinois and United States Department of Agriculture-Agricultural Research Service, Urbana; and UMN = University of Minnesota, St. Paul. 
obtained for the DNA of an isolate (CH11) which was supposedly $F$. virguliforme (Table 3 ). DNA quantities were close to the LOD when positive results were obtained (data not shown). The CH11 DNA was resequenced after the experiment was completed to verify the identification and the sequencing results matched to Sarocladium kiliense.

Detection and estimation of target DNA from root and soil samples. The number of samples diagnosed as positive and the corresponding DNA quantities, averaged over all five laboratories and determined by each assay for the samples from roots and soils,

TABLE 6. Limit of detection (LOD) and percentage of true-positive samples detected by six quantitative polymerase chain reaction assays in three dilutions of $19 \mathrm{~F}$. virguliforme DNA samples, each conducted in laboratories in five different locations ${ }^{\mathrm{y}}$

\begin{tabular}{|c|c|c|c|c|}
\hline \multirow[b]{3}{*}{ Assay, locationz } & \multirow[b]{3}{*}{ LOD (pg) } & \multicolumn{3}{|c|}{ True positive $(\%)$} \\
\hline & & $500(\mathrm{pg})$ & $5(\mathrm{pg})$ & $0.05(\mathrm{pg})$ \\
\hline & & $n=38$ & $n=38$ & $n=38$ \\
\hline \multicolumn{5}{|l|}{ A } \\
\hline ISU & 0.05 & 100.0 & 100.0 & 42.1 \\
\hline MSU & 0.05 & 92.1 & 89.5 & 0.0 \\
\hline SIU & 0.05 & 94.7 & 94.7 & 39.5 \\
\hline UI & 0.05 & 100.0 & 94.7 & 21.1 \\
\hline UMN & 0.05 & 100.0 & 78.9 & 5.3 \\
\hline Mean & $\ldots$ & $97.4 \mathrm{a}$ & $91.6 \mathrm{a}$ & $21.6 \mathrm{a}$ \\
\hline \multicolumn{5}{|l|}{ B } \\
\hline ISU & 0.05 & 100.0 & 100.0 & 52.6 \\
\hline MSU & 0.5 & 86.8 & 28.9 & 0.0 \\
\hline SIU & 0.5 & 94.7 & 94.7 & 10.5 \\
\hline UI & 0.05 & 100.0 & 94.7 & 28.9 \\
\hline UMN & 0.05 & 100.0 & 81.6 & 13.2 \\
\hline Mean & $\ldots$ & $96.3 \mathrm{a}$ & $80.0 \mathrm{~b}$ & $21.1 \mathrm{a}$ \\
\hline \multicolumn{5}{|l|}{ C } \\
\hline ISU & 5 & 94.7 & 68.4 & 5.3 \\
\hline MSU & 0.05 & 92.1 & 44.7 & 0.0 \\
\hline SIU & 5 & 94.7 & 15.8 & 0.0 \\
\hline UI & 0.05 & 100.0 & 94.7 & 28.9 \\
\hline UMN & 0.5 & 100.0 & 92.1 & 44.7 \\
\hline Mean & $\ldots$ & $96.3 \mathrm{a}$ & $63.2 \mathrm{c}$ & $15.8 \mathrm{ab}$ \\
\hline \multicolumn{5}{|l|}{ D } \\
\hline ISU & 5 & 94.7 & 60.5 & 0.0 \\
\hline MSU & 5 & 86.8 & 0.0 & 0.0 \\
\hline SIU & 5 & 84.2 & 31.6 & 2.6 \\
\hline UI & 50 & 73.7 & 0.0 & 0.0 \\
\hline UMN & 5 & 94.7 & 44.7 & 0.0 \\
\hline Mean & $\ldots$ & $86.8 \mathrm{~b}$ & $27.4 \mathrm{e}$ & $0.5 \mathrm{c}$ \\
\hline \multicolumn{5}{|l|}{$\mathrm{E}$} \\
\hline ISU & 5 & 94.7 & 65.8 & 0.0 \\
\hline MSU & 0.05 & 89.5 & 60.5 & 0.0 \\
\hline SIU & 0.5 & 97.4 & 84.2 & 2.6 \\
\hline UI & 0.05 & 100.0 & 94.7 & 31.6 \\
\hline UMN & 0.05 & 100.0 & 89.5 & 44.7 \\
\hline Mean & $\ldots$ & $96.3 \mathrm{a}$ & $78.9 \mathrm{~b}$ & $15.8 \mathrm{ab}$ \\
\hline \multicolumn{5}{|l|}{$\mathrm{F}$} \\
\hline ISU & NA & NA & NA & NA \\
\hline MSU & NA & NA & NA & NA \\
\hline SIU & 5 & 86.8 & 0.0 & 0.0 \\
\hline UI & 0.05 & 100.0 & 94.7 & 26.3 \\
\hline UMN & 0.05 & 92.1 & 57.9 & 0.0 \\
\hline Mean & $\ldots$ & $93.0 \mathrm{a}$ & $50.9 \mathrm{~d}$ & $8.8 \mathrm{bc}$ \\
\hline
\end{tabular}

y LOD for each assay was determined in each lab as the lowest concentration of the standard DNA that could be detected in at least $95 \%$ of the runs. $\mathrm{NA}=$ not available. Assay F did not amplify normally at ISU and MSU so data from those universities for assay $\mathrm{F}$ were not used for analysis. Means per assay were compared using Fisher's least significant difference. Means followed by the same letter within a column do not differ significantly at $P=0.05$.

$\mathrm{z}$ Assay $\mathrm{A}=$ Wang et al. (2015), B = Fakhoury et al. (this study), $\mathrm{C}=\mathrm{Gao}$ et al. (2004), D = Mbofung, et al. (2011), E = Li et al. (2008), and F = Westphal et al. (2014). ISU = Iowa State University, Ames; MSU = Michigan State University, East Lansing; SIU = Southern Illinois University, Carbondale; UI = University of Illinois and United States Department of AgricultureAgricultural Research Service, Urbana; and UMN = University of Minnesota, St. Paul. are given in Table 4. Inhibition due to PCR inhibitors was not observed in any of the field DNA samples, based on the similar amplification of the exogenous control DNA (Haudenshield and Hartman 2011) in field samples and NTC (data not shown). Quantity estimates by each assay in each lab are given in Supplementary Table S2. In general, assays C and E detected greater DNA quantities in field DNA samples than other assays. The most successful detection was obtained using the highest DNA concentration $\left(10^{-1}\right.$ dilution from the stock DNA) and assay A, which detected 37 of 40 reactions tested from infected field roots (four samples from infected fields $\times$ five laboratories $\times$ two technical reps). Assays B, C, D, and $\mathrm{E}$ correctly identified $35,36,26$, and 38 of 40 reactions, respectively, while assay $F$ diagnosed 16 of 24 reactions from inoculated field root samples. One field root sample originating from ISU contained low amounts of DNA and was diagnosed as negative by most of the assays (FV10; Table 4). Quantities of $F$. virguliforme DNA in presumably infested field soil samples was equal to or below the LOD for most of the assays; hence, only $20,8,23,4$, and 26 of 40 reactions were amplified by assays A, B, C, D, and E, respectively (Table 4). Assay F amplified only 4 of 24 reactions of field soil samples. Most of the tests gave negative results for the two infested field soil DNA samples, FV13 and FV21 (Table 4).

All assays detected $F$. virguliforme DNA in infected root samples from the greenhouse. Estimated DNA quantities in infested greenhouse soil were low in all samples. One of the DNA samples extracted from infested greenhouse soil (FV05) was classified as negative by many assays. Surprisingly, most of the assays gave weak amplification to some DNA samples that were expected to be negative. For instance, two DNA samples isolated from nonsymptomatic soybean roots (FV01 and FV08), one soil sample collected from a field with no history of SDS (FV15), and one sample from greenhouse-grown noninoculated soybean root (FV22) were weakly positive. As expected, DNA isolated from noninfested greenhouse soil was diagnosed as negative by most assays but a few false-positive amplifications were observed with assays $\mathrm{C}$ and $\mathrm{E}$ (Table 4).

\section{DISCUSSION}

In this study, six independent qPCR assays that had been developed for detection and quantification of $F$. virguliforme were compared for several parameters in five different research laboratories, using the same panel of 76 DNA samples. We found that the amplification efficiency and the quantity of template DNA measured by qPCR varied across assays and laboratories. In an ideal situation, the amplification efficiency (E) of a PCR reaction is $100 \%$, which means that the amount of initial DNA concentration is doubled each cycle. However, efficiency is affected by many factors, including PCR instrumentation, reagents, assay design, and analysis methods or data interpretation (Bustin 2002; Schefe et al. 2006; Wong and Medrano 2005).

The qPCR assays tested in this study varied in specificity. Specificity is particularly important in SDS research because soybean roots can be infected by several Fusarium spp. or be associated with nonpathogenic Fusarium spp. that are ubiquitous in soil. In the present study, specificity was tested against multiple isolates of 13 different Fusarium spp. and two other common fungi associated with soybean, $R$. solani and M. phaseolina. The FvTox-1based assay (assay D) showed the highest specificity (100\%) in discriminating $F$. virguliforme from nontarget species consistently across the laboratories, whereas the mtSSU-based assays (C and E) were the least specific. This result agrees with the findings of Mbofung et al. (2011) and supports their hypothesis that the sequence of FvToxl gene in $F$. virguliforme is unique and that an assay based on this gene (assay D) could be useful to distinguish $F$. virguliforme from the other SDS pathogens and their close relatives. An in silico analysis of the primers and probes of the various assays reflected the findings of the wet lab data, with assays A and D having the least number of nonspecific hits 
(Supplementary Table S3). Diagnosticians using this assay in some parts of the world where species other than $F$. virguliforme also cause SDS would need to bear in mind that a negative call would not refute SDS incidence, only that it would exclude $F$. virguliforme as the agent.

The discrepancy in specificity among the assays compared in this study was most likely related to the variability in the regions targeted for amplification. The earliest developed assays (Gao et al. 2004; Li et al. 2008) used highly conserved loci and, thus, were not species specific (Mbofung et al. 2011; O'Donnell et al. 2010). Another challenge to the development of qPCR tools for $F$. virguliforme has been the taxonomic revisions of Fusarium spp. Initially, the SDS-causing pathogen was called $F$. solani form A (Roy et al. 1989), which was reclassified and renamed as $F$. solani f. sp. glycines in 1997 (Roy 1997), and then F. virguliforme in 2003 (Aoki et al. 2003). The SDS and closely related bean root rot pathogens fall within clade 2 of the $F$. solani species complex (O'Donnell et al. 2010). Assays C and E that were developed prior to the recent classification or without considering the species diversity within clade 2 of the $F$. solani species complex failed to delimit $F$. virguliforme from closely related species (O'Donnell et al. 2010), whereas assays A, D, and F were successful in that discrimination. Assay B was developed for the simultaneous detection and quantification of all fusaria causing SDS, including $F$. virguliforme, $F$, brasiliense, $F$. tucumaniae, and $F$ crassistipitatum. Assay B did not show specificity to SDS-causing species within clade 2 of the $F$. solani species complex clade but it did not amplify fusaria outside this clade.

Inclusivity, the ability to include all the $F$. virguliforme isolates, was tested against 19 different $F$. virguliforme isolates originating from different geographical regions. The average inclusivity across laboratories for each assay ranged from 87 to $97 \%$. Inclusivity was affected by an inconsistent result of one of the supposedly $F$. virguliforme isolate DNA (CH11). Resequencing after completion of the runs did not verify the identification because the sequence matched with an unrelated genus. This suggests that the sample might have been contaminated during sample preparation. Therefore, the assay that was least sensitive might have been failed to amplify, while others with higher sensitivity showed inconsistency due to the low amount of $F$. virguliforme DNA in the contaminated sample. In general, our study suggests that all assays, except D, had high inclusivity (above 93\%) despite the genetic diversity (Mbofung et al. 2012) and variability in aggressiveness (Li et al. 2009; Malvick and Bussey 2008) reported for F. virguliforme.

Sensitivity, the ability to reliably detect a small amount of target DNA, is another critically important component of any qPCR assay. The present study showed that the LOD varied across the assays, with the assays based on multiple-copy genes having lower LOD (100-fold greater sensitivity) than assays based on single-copy genes. This is consistent with previous studies (Chern et al. 2011; Wang et al. 2015) showing that the assays that amplify multicopy target regions have lower detection limits and provide greater analytical sensitivity than assays targeting a single-copy gene. Assay A consistently showed the greatest sensitivity with the lowest detection limit (i.e., $0.05 \mathrm{pg}$ ) and highest true-positive detection rate across all laboratories. However, some of the other assays also showed the same LOD of $0.05 \mathrm{pg}$ in two or more of the laboratories where they were tested. This illustrates the degree to which differing reagents and instruments may affect the performance of the assays. The 0.05-pg LOD corresponds to an approximately two-haploidnuclei genome based on an estimated 51-Mbp genome size of the species (Srivastava et al. 2014) and, thus, the assays are likely

TABLE 7. Specificity and inclusivity of six quantitative polymerase chain reaction assays developed to detect and quantify Fusarium virguliforme determined in laboratories in five different locations $\mathrm{s}^{\mathrm{x}}$

\begin{tabular}{|c|c|c|c|c|c|c|c|c|c|c|c|c|}
\hline \multirow[b]{3}{*}{ Location $^{z}$} & \multicolumn{12}{|c|}{ Assay ${ }^{y}$} \\
\hline & \multicolumn{6}{|c|}{ Specificity $(\%)$} & \multicolumn{6}{|c|}{ Inclusivity (\%) } \\
\hline & A & B & $\mathrm{C}$ & $\mathrm{D}$ & $\mathrm{E}$ & $\mathrm{F}$ & A & B & $\mathrm{C}$ & $\mathrm{D}$ & $\mathrm{E}$ & $\mathrm{F}$ \\
\hline MSU & 98.6 & 75.7 & 62.9 & 98.6 & 40.0 & NA & 92.1 & 86.8 & 92.1 & 86.8 & 89.5 & NA \\
\hline SIU & 94.3 & 71.4 & 35.7 & 100.0 & 48.6 & 95.7 & 94.7 & 94.7 & 94.7 & 84.2 & 97.4 & 86.8 \\
\hline UI & 90.0 & 62.9 & 55.7 & 100.0 & 42.9 & 92.9 & 100.0 & 100.0 & 100.0 & 73.7 & 100.0 & 100.0 \\
\hline UMN & 95.7 & 68.6 & 18.6 & 100.0 & 21.4 & 100.0 & 100.0 & 100.0 & 100.0 & 94.7 & 100.0 & 92.1 \\
\hline
\end{tabular}

${ }^{\mathrm{x}}$ Specificity (the ability to detect only $F$. virguliforme) and inclusivity (the ability to detect all $F$. virguliforme isolates tested) of each assay were calculated using the following formulas: Specificity $=1-($ number of FP at $0.5 \mathrm{ng}$ DNA concentration $/[\mathrm{TN}+\mathrm{FP}]) \times 100$ where $\mathrm{FP}=$ false positive and TN $=$ true negative; Inclusivity $=$ (number of true positives at $0.5 \mathrm{ng}$ DNA concentration/total number of F. virguliforme samples $) \times 100$ NA $=$ not available. Assay F failed to amplify normally at Iowa State University, Ames (ISU) and Michigan State University, East Lansing (MSU); therefore, data from those universities for assay F were not used in the analysis. Mean specificity and inclusivity were compared using Fisher's least significant difference. Means followed by the same letter within a variable do not differ significantly at $P=0.05$.

y Assay A = Wang et al. (2015), B = Fakhoury et al. (this study), C = Gao et al. (2004), D = Mbofung, et al. (2011), E = Li et al. (2008), and F = Westphal et al. (2014).

z SIU = Southern Illinois University, Carbondale; UI = University of Illinois and United States Department of Agriculture-Agricultural Research Service, Urbana; and UMN = University of Minnesota, St. Paul.

TABLE 8. Summary of key comparative performance variables among quantitative polymerase chain reaction assays for $F$. virguliforme shown as average values or ranges obtained in five laboratories ${ }^{y}$

\begin{tabular}{lccccc}
\hline Assayz $^{2}$ & Specificity (\%) & Inclusivity (\%) & False positives (\%) & False negatives (\%) & Sensitivity range across labs \\
\hline A & $94.6 \mathrm{~b}$ & $97.4 \mathrm{a}$ & 5.4 & 2.6 & 0.05 \\
$\mathrm{~B}$ & $70.3 \mathrm{c}$ & $96.3 \mathrm{a}$ & 29.7 & 3.7 & 0.05 to 0.5 \\
C & $47.2 \mathrm{~d}$ & $96.3 \mathrm{a}$ & 52.9 & 3.7 & 0.05 to 5.0 \\
D & $99.7 \mathrm{a}$ & $86.8 \mathrm{~b}$ & 0.3 & 13.2 & 3.7 \\
E & $40.9 \mathrm{e}$ & $96.3 \mathrm{a}$ & 59.1 & 7.0 & 0.05 to 5.0 \\
F & $96.2 \mathrm{~b}$ & $93.0 \mathrm{a}$ & 3.8 & 0.0 & 0.05 to 5.0 \\
\hline
\end{tabular}

y Higher values are better for specificity and inclusivity and lower values are better for false positives, false negatives, and sensitivity. Means per assay were compared using Fisher's least significant difference. Means followed by the same letter within a variable do not differ significantly at $P=0.05$.

${ }^{\mathrm{z}}$ Assay A = Wang et al. (2015), B = Fakhoury et al. (this study), C = Gao et al. (2004), D = Mbofung, et al. (2011), E = Li et al. (2008), and F = Westphal et al. (2014). 
detecting a very small quantity of $F$. virguliforme DNA, as enabled by the multicopy nature of the target sequence. In contrast, the lowest sensitivity was observed in the single-copy gene FvToxlbased assay $\mathrm{D}$. The difference in sensitivity among the assays was clearly observed with the true-positive rate at the concentration of DNA at $5 \mathrm{pg} /$ well, although most of the assays detected nearly all positive samples in the highest concentration (500 pg of DNA). The maximum positive sample detection rate of DNA at $5 \mathrm{pg} /$ well $(92 \%)$ was observed for assay A, while assay D only detected $27 \%$ of these samples.

Although the present study showed a positive correlation among the qPCR assays for the quantity of DNA estimated in field samples, assays $\mathrm{C}$ and $\mathrm{E}$ yielded a higher quantity of DNA more frequently than all other assays did, probably due to amplification of nontarget species by those assays. A few presumably infested or noninfested field samples did not produce results (positive or negative amplification, respectively) as expected, possibly due to factors such as patchy distribution of the pathogens in the field, levels of $F$. virguliforme below LOD, and unknown long-term history of the fields that may have resulted in misdiagnosis of the samples. In contrast, $F$. virguliforme was detected in all artificially infected greenhouse roots by all assays.

The discrepancies in specificity and sensitivity observed in our study, among the assays and across the laboratories on the same set of DNA samples, underlines the fact that the performance of an assay is influenced by factors such as reagents and equipment used. For example, in this study, the recently published assay $\mathrm{F}$ (Westphal et al. 2014) did not consistently amplify samples in two of the five participating laboratories but the assay gained functionality in those laboratories when the annealing temperature was changed from the $66^{\circ} \mathrm{C}$ described in the publication (Westphal et al. 2014) to $60^{\circ} \mathrm{C}$ (data not shown). This supports the suggestion that some instruments or master mixes may not perform similarly and assays may need to be modified or calibrated for optimization in some situations (Espy et al. 2006; Khot et al. 2008). Therefore, it is possible that parameters such as efficiency and sensitivity might have been different if each assay had been run with the optimized reagents used by its developer in all labs.

To summarize, this study was undertaken neither to approve nor discredit any of the published assays but to compare strengths and weaknesses of several methods in quantifying $F$. virguliforme in infected plant material and infested soil, and to identify variables that may affect one or more of the assays. The comparison showed that the single-copy gene FvToxl and the IGS sequence are good target regions for $F$. virguliforme-specific assays. Specificity varied highly among assays. The FvToxl gene-based assay (assay D) was the most specific (100\%), while two IGS assays (assays A and F) were slightly less specific (95 to $96 \%$ ) and $\mathrm{mtSSU}$ assays were the least specific (41 and 47\%). Multicopy-gene-based assays were more sensitive (LOD 0.05 to $5 \mathrm{pg}$ ) than the single-gene-based assay FvToxl (LOD = 5 to $50 \mathrm{pg}$ ) (Table 8); thus, assay D may not be suited for analyzing samples having low pathogen density. Assay A showed the highest sensitivity (LOD $=0.05 \mathrm{pg}$ ) consistently across the laboratories. All other assays, however, except assay D, also showed the same low detection limit of $0.05 \mathrm{pg}$ in two or more of the laboratories where they were tested (Table 8). Assay A showed high specificity (95\%) and inclusivity (97\%) along with the consistently highest sensitivity, which made this assay potentially the most useful for $F$. virguliforme, where high specificity and sensitivity is needed. However, the choice of assay for diagnosis or research will also depend on objectives, equipment, and reagents. Some studies may need the highest level of specificity and some may need higher sensitivity, and those parameters may be influenced by the materials and instruments available in a particular lab. For example, assay specificity might be less important in greenhouse studies where a known species is added to pasteurized soil and, in such a situation, an assay that has performed well under the specific conditions of that lab may be a better choice. Regardless, the results show that qPCR can be used for quantification of $F$. virguliforme population density in plants and natural fields and may guide researchers in selecting an assay appropriate to their instrumentation and experimental needs. This may lead to improved disease diagnosis, research on SDS, and the ability of farmers to make more informed decisions on management strategies for SDS.

\section{ACKNOWLEDGMENTS}

Support for this study was partially provided by the North Central Soybean Research Program. We thank G. Munkvold and M. Ellis for providing isolates of $F$. solani, $F$. oxysporum $F$. accuminatum, F. sprotrichoides, and F. graminearum; J. Banta at the University of Illinois, Urbana; and C. Anderson and N. Abdelsamad from ISU for assistance in the laboratory.

\section{LITERATURE CITED}

Anderson, T., and Tenuta, A. 1998. First report of Fusarium solani f. sp. glycines causing sudden death syndrome of soybean in Canada. Plant Dis. $82: 448$.

Aoki, T., O’Donnell, K., Homma, Y., and Lattanzi, A. R. 2003. Suddendeath syndrome of soybean is caused by two morphologically and phylogenetically distinct species within the Fusarium solani species complex $-F$. virguliforme in North America and $F$. tucumaniae in South America. Mycologia 95:660-684.

Aoki, T., O'Donnell, K., and Scandiani, M. M. 2005. Sudden death syndrome of soybean in South America is caused by four species of Fusarium: Fusarium brasiliense, F. cuneirostrum, F. tucumaniae, and F. virguliforme. Mycoscience 46:162-183.

Aoki, T., Scandiani, M., and O’Donnell, K. 2012. Phenotypic, molecular phylogenetic, and pathogenetic characterization of Fusarium crassistipitatum, a novel soybean sudden death syndrome pathogen from Argentina and Brazil. Mycoscience 53:167-186.

Bilodeau, G. J. 2011. Quantitative polymerase chain reaction for the detection of organisms in soil. CAB Rev. Perspect. Agric. Vet. Sci. Nutr. Nat. Resour. $6: 1-14$.

Brar, H. K., Swaminathan, S., and Bhattacharyya, M. K. 2011. The Fusarium virguliforme toxin FvTox1 causes foliar sudden death syndrome-like symptoms in soybean. Mol. Plant-Microbe Interact. 24:1179-1188.

Bustin, S. 2002. Quantification of mRNA using real-time reverse transcription PCR (RT-PCR): Trends and problems. J. Mol. Endocrinol. 29:23-39.

Bustin, S. A. 2010. Why the need for qPCR publication guidelines?-The case for MIQE. Methods 50:217-226.

Chern, E. C., Siefring, S., Paar, J., Doolittle, M., and Haugland, R. A. 2011. Comparison of quantitative PCR assays for Escherichia coli targeting ribosomal RNA and single copy genes. Lett. Appl. Microbiol. 52:298-306.

Cho, J., Rupe, J., Cummings, M., and Gbur, E., Jr. 2001. Isolation and identification of Fusarium solani f. sp. glycines from soil on modified Nash and Snyder's medium. Plant Dis. 85:256-260.

Espy, M. J., Uhl, J. R., Sloan, L. M., Buckwalter, S. P., Jones, M. F., Vetter, E. A., Yao, J. D. C., Wengenack, N. L., Rosenblatt, J. E., Cockerill, F. R., and Smith, T. F. 2006. Real-time PCR in clinical microbiology: Applications for routine laboratory testing. Clin. Microbiol. Rev. 19:165-256.

Gao, X., Jackson, T., Lambert, K., Li, S., Hartman, G., and Niblack, T. 2004. Detection and quantification of Fusarium solani f. sp. glycines in soybean roots with real-time quantitative polymerase chain reaction. Plant Dis. 88: 1372-1380.

Hartman, G. L., Leandro, L. F. S., and Rupe, J. C. 2015a. Sudden death syndrome. Pages 88-90 in: Compendium of Soybean Diseases and Pests. G. L. Hartman, J. C. Rupe, E. F. Sikora, L. L. Domier, J. A. Davis, and K. L. Steffey, eds. American Phytopathological Society, St. Paul, MN.

Hartman, G. L., Rupe, J. C., Sikora, E. F., Domier, L. L., Davis, J. A., and Steffey, K. L. 2015b. Compendium of Soybean Diseases and Pests. American Phytopathological Society, St. Paul, MN.

Haudenshield, J. S., and Hartman, G. L. 2011. Exogenous controls increase negative call veracity in multiplexed, quantitative PCR assays for Phakopsora pachyrhizi. Plant Dis. 95:343-352.

Heid, C. A., Stevens, J., Livak, K. J., and Williams, P. M. 1996. Real time quantitative PCR. Genome Res. 6:986-994.

Hirrel, M. C. 1983. Sudden death syndrome of soybean-A disease of unknown etiology. (Abstr.) Phytopathology 73:501.

Khot, P., Ko, D., Hackman, R., and Fredricks, D. 2008. Development and optimization of quantitative PCR for the diagnosis of invasive aspergillosis with bronchoalveolar lavage fluid. BMC Infect. Dis. 8:73.

Leandro, L. F., Tatalovic, N., and Luckew, A. 2012. Soybean sudden death syndrome-Advances in knowledge and disease management. CAB Rev. $7: 1-14$. 
Lemmon, G., and Gardner, S. 2008. Predicting the sensitivity and specificity of published real-time PCR assays. Ann. Clin. Microbiol. Antimicrob. 7:18.

Li, S., and Hartman, G. 2003. Molecular detection of Fusarium solani f. sp. glycines in soybean roots and soil. Plant Pathol. 52:74-83.

Li, S., Hartman, G., and Chen, Y. 2009. Evaluation of aggressiveness of Fusarium virguliforme isolates that cause soybean sudden death syndrome. J. Plant Pathol. 91:77-86.

Li, S., Hartman, G. L., Domier, L. L., and Boykin, D. 2008. Quantification of Fusarium solani f. sp. glycines isolates in soybean roots by colony-forming unit assays and real-time quantitative PCR. Theor. Appl. Genet. 117:343-352.

Luo, Y., Chong, S. K., and Myers, O. 2001. Spatio-temporal analysis of soybean root colonization by Fusarium solani f. sp. glycines in fields. Plant Dis. 85:303-310.

Luo, Y., Hildebrand, K., Chong, S., Myers, O., and Russin, J. 2000. Soybean yield loss to sudden death syndrome in relation to symptom expression and root colonization by Fusarium solani f. sp. glycines. Plant Dis. 84:914-920.

Malvick, D., and Bussey, K. 2008. Comparative analysis and characterization of the soybean sudden death syndrome pathogen Fusarium virguliforme in the northern United States. Can. J. Plant Pathol. 30:467-476.

Malvick, D. K., and Grunden, E. 2005. Isolation of fungal DNA from plant tissues and removal of DNA amplification inhibitors. Mol. Ecol. Notes 5: 958-960

Mbofung, G., Fessehaie, A., Bhattacharyya, M., and Leandro, L. 2011. A new TaqMan real-time polymerase chain reaction assay for quantification of Fusarium virguliforme in soil. Plant Dis. 95:1420-1426.

Mbofung, G. Y. C., Harrington, T. C., Steimel, J. T., Navi, S. S., Yang, X. B., and Leandro, L. F. 2012. Genetic structure and variation in aggressiveness in Fusarium virguliforme in the Midwest United States. Can. J. Plant Pathol. 34:83-97.

McCartney, H. A., Foster, S. J., Fraaije, B. A., and Ward, E. 2003. Molecular diagnostics for fungal plant pathogens. Pest Manage. Sci. 59:129-142.

Mueller, D. S., Nelson, R. L., Hartman, G. L., and Pedersen, W. L. 2003. Response of commercially developed soybean cultivars and the ancestral lines to Fusarium solani f. sp. glycines. Plant Dis. 87:827-831.

Mumford, R., Boonham, N., Tomlinson, J., and Barker, I. 2006. Advances in molecular phytodiagnostics-New solutions for old problems. Eur. J. Plant Pathol. 116:1-19.

O’Donnell, K., Kistler, H. C., Cigelnik, E., and Ploetz, R. C. 1998. Multiple evolutionary origins of the fungus causing Panama disease of banana: Concordant evidence from nuclear and mitochondrial gene genealogies. Proc. Natl. Acad. Sci. USA 95:2044-2049.

O’Donnell, K., Sink, S., Scandiani, M. M., Luque, A., Colletto, A., Biasoli, M., Lenzi, L., Salas, G., González, V., and Ploper, L. D. 2010. Soybean sudden death syndrome species diversity within North and South America revealed by multilocus genotyping. Phytopathology 100:58-71.

Prathuangwong, S., Saisangthong, S., Dareaudee, A., and Chutawantana, P. 1996. The incidence and new occurrence of soybean disease in central area during 1994-1996. Pages 242-258 in: Proc. Soybean Res. Conf. VI. Kasetsart University, Pub, Bangkok, Thailand. (In Thai with English abstract)

Pudake, R. N., Swaminathan, S., Sahu, B. B., Leandro, L. F., and Bhattacharyya, M. K. 2013. Investigation of the Fusarium virguliforme FvToxl mutants revealed that the FvTox 1 toxin is involved in foliar sudden death syndrome development in soybean. Curr. Genet. 59:107-117.
Roy, K., Hershman, D., Rupe, J., and Abney, T. 1997. Sudden death syndrome of soybean. Plant Dis. 81:1100-1111.

Roy, K., Lawrence, G., Hodges, H., Mclean, K., and Killebrew, J. 1989. Sudden death syndrome of soybean: Fusarium solani as incitant and relation of Heterodera glycines to disease severity. Phytopathology 79: 191-197.

Roy, K. W. 1997. Fusarium solani on Soybean Roots: Nomenclature of the causal agent of sudden death syndrome and identity and relevance of F. solani form B. Plant Dis. 81:259-266.

Rupe, J., Correll, J. C., Guerber, J. C., Becton, C. M., Gbur, E. E., Jr., Cummings, M. S., and Yount, P. 2001. Differentiation of the sudden death syndrome pathogen of soybean, Fusarium solani f. sp. glycines, from other isolates of $F$. solani based on cultural morphology, pathogenicity, and mitochondrial DNA restriction fragment length polymorphisms. Can. J. Bot. 79:829-835.

Rupe, J., and Hartman, G. 1999. Sudden death syndrome. Pages 37-39 in: Compendium of Soybean Diseases. G. L. Hartman, J. B. Sinclair, and J. C. Rupe, eds. American Phytopathological Society, St. Paul, MN.

Sanitchon, J., Vanavichit, A., Chanprame, S., Toojinda, T., Triwitayakorn, K., Njiti, V. N., and Srinives, P. 2004. Identification of simple sequence repeat markers linked to sudden death syndrome resistance in soybean. Sci. Asia 30:205-209.

Sanzani, S. M., Li Destri Nicosia, M. G., Faedda, R., Cacciola, S. O., and Schena, L. 2014. Use of quantitative PCR detection methods to study biocontrol agents and phytopathogenic fungi and oomycetes in environmental samples. J. Phytopathol. 162:1-13.

Schefe, J., Lehmann, K., Buschmann, I., Unger, T., and Funke-Kaiser, H. 2006. Quantitative real-time RT-PCR data analysis: Current concepts and the novel "gene expression's CT difference" formula. J. Mol. Med. 84: 901-910.

Schena, L., Li Destri Nicosia, M., Sanzani, S., Faedda, R., Ippolito, A., and Cacciola, S. 2013. Development of quantitative PCR detection methods for phytopathogenic fungi and oomycetes. J. Plant Pathol. 95:7-24.

Srivastava, S. K., Huang, X., Brar, H. K., Fakhoury, A. M., Bluhm, B. H., and Bhattacharyya, M. K. 2014. The genome sequence of the fungal pathogen Fusarium virguliforme that causes sudden death syndrome in soybean. PLoS One 9:e81832.

Tewoldemedhin, Y. T., Lamprecht, S. C., Geldenhuys, J. J., and Kloppers, F. J. 2014. First report of soybean sudden death syndrome caused by Fusarium virguliforme in South Africa. Plant Dis. 98:569.

Torto, G., Njiti, V., and Lightfoot, D. 1996. Loci underlying resistance to sudden death syndrome and Fusarium solani in field and greenhouse assays do not correspond. Soybean Genet. News1. 23:163-166.

Vincelli, P., and Tisserat, N. 2008. Nucleic acid-based pathogen detection in applied plant pathology. Plant Dis. 92:660-669.

Wang, J., Jacobs, J. L., Byrne, J. M., and Chilvers, M. I. 2015. Improved diagnoses and quantification of Fusarium virguliforme, causal agent of soybean sudden death syndrome. Phytopathology 105:378-387.

Westphal, A., Li, C., Xing, L., McKay, A., and Malvick, D. 2014. Contributions of Fusarium virguliforme and Heterodera glycines to the disease complex of sudden death syndrome of soybean. PLoS One 9:e99529.

Wong, M. L., and Medrano, J. F. 2005. Real-time PCR for mRNA quantitation. Biotechniques 39:75-85. 